J OURNAL OF French and Francophone Philosophy
REVUE DE LA

philosophie française et de langue française

\title{
Not to be European would not be 'to be European still': Undoing Eurocentrism in Levinas and Others
}

Avram Alpert

Journal of French and Francophone Philosophy - Revue de la philosophie française et de langue française, Vol XXIII, No 1 (2015) pp 21-41.

\author{
Vol XXIII, No 1 (2015) \\ ISSN 1936-6280 (print) \\ ISSN 2155-1162 (online) \\ DOI $10.5195 /$ jffp. 2015.622 \\ www.jffp.org
}

\section{(c) EY-NC-NO}

This work is licensed under a Creative Commons Attribution-Noncommercial-No Derivative Works 3.0 United States License.

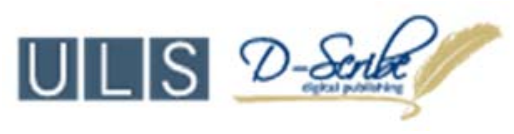

This journal is operated by the University Library System of the University of Pittsburgh as part of its D-Scribe Digital Publishing Program, and is co-sponsored by the University of Pittsburgh Press 


\title{
Not to be European would not be
}

\section{'to be European still': Undoing Eurocentrism in Levinas and Others}

\author{
Avram Alpert \\ Rutgers University
}

Emmanuel Levinas' philosophy begins in the other. This much is well known. But once we start to ask questions about the specifics of this other, complications ensue. How is it that a relationship of peace is developed if I am "subjected" and "taken hostage" by the other? What is the relation to other others - the infamously ambiguous "third" of Levinasian politics? And what about the specific conditions of the other? Do others have a gender, a race, an ethnicity? Do we have different relations to others based on such social coordinates? ${ }^{1}$

With the work of scholars including Robert Bernasconi, Judith Butler, Simon Critchley, John Drabinski, and Nelson Maldonado-Torres, a more specific form of this question has come in to view; namely, what is Levinas' relation to the non-European other? ${ }^{2}$ The problem for these thinkers has repeatedly been that Levinas' political statements - often expressing a distaste and even hostility for non-Europeans - seem so far removed from his avowed ethics. When Levinas states, for example, that "I always say - but in private - that the Greeks and the Bible are all that is serious in humanity. Everything else is dancing,"3 one wonders how applicable his ethical philosophy might be in a global world.

Although not to the extent of the controversies caused by thinkers who had varying degrees of proximity to Nazism, Levinas' questionable remarks have caused problems for those who have espoused his thought. Perhaps most remarkable, of course, is that Levinas' reputation as a philosopher rests to a large extent on his early diagnosis of Heidegger's Nazism and his formulation of an ethics of the other in part as a response. The irony of this situation is that his critique of Heidegger (and Western philosophy more generally) and his critique of non-European ways of thinking start from a similar premise: "Every civilization that accepts being - with the tragic despair it contains and the crimes it justifies - merits the name 'barbarian."'4 
In a curious way, Heidegger and the "dancing primitives" share the same problem for Levinas - too much attachment to the elements, to the earth, to the body. They cannot get out of being. They lack transcendence, and in lacking transcendence they are chained to the instinctual passions and the failure of ethical subjectivity that enabled the catastrophe of the Holocaust. The barbarian, the primitive, the pagan, the Heideggerian. They all name, at least from a certain vantage, the same failure for Levinas. ${ }^{5}$ This essay tracks the place of this "unthinking" figure of the primitive in Levinas' thought.

As with Bernasconi, Butler, Drabinski, and others, I am trying in this analysis to understand what is valuable in Levinas' philosophy while at the same time remaining true to its failings. The difference I am proposing is that while for most of these scholars a wedge can be made between Levinas' philosophy and his Eurocentrism, allowing his ethics to prosper and his mistakes to be excised, I propose that his critique of so-called primitive life is fundamentally constitutive of his philosophy. ${ }^{6}$ In other words, I am arguing that before we engage Levinas in a global dialogue, we need first to tarry with this problematic node in his thought. This needs a qualification, for, as Drabinski warns, simply "trott[ing] out" Levinas' questionable remarks without serious analysis runs the risk of making it "all a matter of gossip and moralizing gasps."7 Indeed, my argument is not that Levinas need be thought of as having an irremediably racist ethics. Rather, it is that his ethical thought is bound up with a conception of primitive life as unthinking which is neither, I will argue, anthropologically tenable, nor philosophically innocent. In uncovering the place of that conception in his work, I hope to open it up to more profitable future engagements with global philosophies.

The essay that follows begins with a quick overview of the major points of Levinas' philosophy via a reading of "God and Philosophy" (1975). ${ }^{8}$ It then reiterates a claim of other Levinas scholarship that some of his earliest writings - "Reflections on the Philosophy of Hiterlism" (1934), On Escape (1935), and some of his Jewish writings for Paix et Droit (1933-1935) - show the roots of his simultaneous critique of Western philosophy and primitivism. ${ }^{9}$ This critique is shown to be in a direct line to the formulation of his first major philosophical work, Totality and Infinity (1961), particularly via two essays which preceded it: "Philosophy and the Idea of Infinity" and "Lévy-Bruhl and Contemporary Philosophy" (both from 1957). The major claim being advanced in this section is that the formulation of Levinas' major philosophy is inseparable from his critique of non-Europeans, all of whom he seems to consider unreasonable primitives. A final look at his 1984 essay, "Peace and Proximity" shows that this prejudice remains through the whole of Levinas' career.

Finally, through a reading of a late text by Jacques Derrida on the question of Judaism, I suggest that Levinas' ethics is missing a crucial first step - an originary agnostic moment - which, already latent in his philosophy, offers a solution to the ethical problem. Using Levinas' idea of 
the "pre-original" in dialogue with Derrida's critique, I suggest a possible opening to a Levinasian philosophy that does not presume the naïve immersion of the non-European. Thus, where scholars have previously tried to remove a supposed afterthought of Levinas' work, my aim, following Derrida, is to unhinge the problem before the philosophy gets started. In essence, the problem that will unfold is that Levinas creates a concept of Europe that becomes the necessary precursor to thinking an ethical relation to the other. What is being sought here, via Levinas' dialogue with Derrida, is a non-Eurocentric space from which to think this thought of ethical subjectivity.

This essay, then, is arguing on two fronts: one specific to Levinas, and one about the relationship of ethics to geography more generally. With regard to Levinas, I suggest that the link between his thought and antipaganism needs to be taken more seriously. That anti-paganism cannot be excised from his thought, but it can be dislodged. With regard to ethics more generally, I am writing against an idea of European supremacy that remains current in contemporary philosophy. The trouble here is not with Europe, but with the supremacy imputed to it. Ideas from European philosophers remain important, and the geographical abstraction "Europe" is not meaningless. But when thinkers argue - as Levinas himself did - that the very idea of opening to others was a European invention, or that thinkers outside Europe have nothing meaningful to contribute to philosophy, we need to respond that this is both historically inaccurate and conceptually absurd. There are both other spaces that have produced an ethics of encounter, and there are other ethics that have been produced in other spaces. The point is neither to insist on the uniqueness and power of one geography, nor is it to oppose a way of thinking simply because a cluster of thinkers in a particular region espoused it. Rather, it is to engage in comparative work that shows both similarity and difference across ethical formations. Part of this work can be done by showing how such comparisons - as in Levinas' engagements with anthropology - have already taken place, and, due to their problematic assumptions, are providing a misshapen contour to our thought. It is my hope in this essay that by opening Levinas' work up to new dialogic potentials, I can contribute in some small way to the continuing effort to overcome Eurocentrism in philosophy today. ${ }^{10}$

\section{Levinas' "God and Philosophy"}

No brief summary of Levinas' philosophy - which so often finds its finest moments in the details, in the descriptions of insomnia, the difficult language of substitution, the phenomenology of the caress - can do justice to his work. Nor can we be satisfied to repeat Levinas' "one great thought" that ethics is first philosophy, "where ethics is understood as a relation of infinite 
responsibility to the other person,"11 for this will not help us arrive at the significance that the rejection of primitivism will have for Levinas' philosophy. Rather, following Critchley and others, we need to understand the specific way in which Levinas thinks ethical subjectivity. The claim I will be defending throughout this essay is as follows: Levinas seeks an ethical subjectivity that is neither purely instinctual (that is, is not immersed in being and blunt reaction), nor purely rational (that is, totalizing and irreconcilably transcendent of being). We shall see that such pure instinct and immersion is what Levinas aligns with primitivism, and such rationality would be at best "an indifferent region, in a void,"12 but more likely would mark the structure of totality and sameness which generates war. ${ }^{13}$

Levinas' ethical subjectivity refuses both of these options and turns instead to a Biblical resolution. In "God and Philosophy," he criticizes Western philosophy (with two exceptions which we will come to) of having "been a destruction of transcendence."14 Phenomenology, even though it had earlier held out for him the promise of a mediation between reason and immersion, ultimately proved inadequate by conceiving a subjective consciousness which can continually re-present itself with the claim "I think," that is, a claim to a unity of a subject which can apprehend the world. For Levinas, this is too close to immanence, and in a negative sense: it names consciousness in the act of being; it is incapable of transcending being. It is here that Levinas turns to Descartes. The crucial idea is not Descartes' idea of God (which for Levinas remains tethered to a concept of being), but rather that God presents for Descartes a thought greater than what the subject can think. In other words, infinity names the fact that there can be no transcendental ego which could apprehend all. Only the thought of infinity for Levinas breaks outside the realm of being, of the fully present, "I think."

Levinas now needs to relate this notion of infinity to consciousness. If consciousness is understood to be receptivity, then the relation is false. Thought here is not receptive; it is passive: the idea of infinity is "put into us" (GP 137). But, Levinas asks, is this then just the Socratic theory of memory as it appears in the Phaedrus - a truth we have forgotten but can remember? This cannot be, for anamnesis is still a content-based memory. Infinity is more passive than this in the sense that it creates nothing, it synthesizes nothing, it conceptualizes nothing. Infinity is the break-up of consciousness as such.

Levinas thus needs a way to interpret and explicate infinity outside of these constraints. He goes through various ways that traditional philosophy might try to ensnare this meaning - a simple opposition of finite/infinite, or a concept of adequation between reality and the thought. But Levinas insists that the idea of infinity shatters subjectivity, consciousness, and experience, and so cannot be named in any of these terms. Relying on the second privileged moment of transcendence in the history of Western philosophy (Descartes was the first), Levinas begins to sketch a way of describing 
infinity through reference to a desire for the "good beyond Being" (a phrase he takes from Plato). Desire is then this yearning for transcendence, but, Levinas immediately asks, is there not a danger that desire will seek a particular content - the desirable - and then are we not back in the world of interests and correspondences? Levinas has his concept of infinity, and he has shattered our notions of consciousness, subjectivity and experience. He will now aim to define desire otherwise than as based in content.

He begins this articulation by arguing against the form of desire found in Plato's Symposium, that is, desire as both nostalgia and completion. Desire for Levinas is not satisfaction but rather "the increase of hunger" (GP 140). What this turns us toward is not the other who completes me, but the other who overwhelms me. In Otherwise than Being Levinas speaks of the subject as hostage/ persecuted / accused/ obsessed / subjected. In so doing he redefines subjectivity (which he claims is usually reduced to mere consciousness) as subjection to the other. Ethics is thus not first philosophy because it should be; ethics is first philosophy because that is the fact of subjectivity - subjected to a relation with the other (an other who is also marked by infinity) in its very inception. This will prove crucial in our reading of Levinas' anti-primitivism. We cannot merely say that he should not have been; we need to show that his description of the situation is inaccurate.

Levinas goes on, in about a page and a half of the essay, to show why Hobbes, Hegel, Heidegger, and Sartre are all wrong in their theories of freedom and responsibility. ${ }^{15}$ (This accounts for some of the difficulty of Levinas' writing!) In brief, Hobbes is wrong because he presupposes war and not the infinity of the ethical relation; Hegel and Sartre are wrong because they presuppose freedom; Heidegger is wrong because he presupposes a concern with one's own being as primary. Levinas' general claim is thus that all of these accounts presuppose something, freedom or choice, which is in fact secondary to the act of being chosen. Thus "responsibility does not give one time, a present for recollection or coming back to oneself; it makes one always late" (GP 143).

It is in this moment that we get our biblical resolution. Levinas offers two possible moments that live up to this status of an "unmeasured responsibility." First is Abraham's "'I am dust and ashes'" and, "more humbly," Moses' "'What are we'"? But neither quite fulfills the demand as one names itself, and the other simply poses a question, however humbly. To speak to the "I torn from the concept of the ego" we need not a statement, but a response; specifically, Abraham's response to the call of God. "This is that I that is not designated but which says, 'here I am"' (GP144). ${ }^{16}$ What is striking in Levinas' work is that this is the only possible response. Only the monotheistic, "Here I am," is able to adequately locate itself in the space of responsible subjectivity, which is neither immersed in the world nor fully 
transcendent of it. It alone responds to the call to pull oneself out of being without completely transcending life.

\section{Levinas' God and Philosophy against the Primitives}

It will not be difficult to see how these concerns play out in Levinas' writings themselves, but it is worth noting that the generation of the problem of producing a way of thinking that is neither purely instinctual nor too obsessed with reason partakes of a legacy of writing about primitivism. This is perhaps most clear in Rousseau. ${ }^{17}$ Though not entirely a primitivist himself, Rousseau was sympathetic to its claims. ${ }^{18}$ In the travelogues he (mis)read, he claimed to find people whose souls, immersed in everyday life, were not agitated by the injustices and shattered experiences of civilized life. At the same time, he believed that a life without reflection and reason lacked foresight and hence the capacity to form just communities. It is in civilization, he writes in On the Social Contract, that a person for the first time "substitutes justice for instinct... Only then, when the voice of duty replaces physical impulse...does man...find himself forced to act upon other principles and to consult his reason before listening to his inclinations."19 What Rousseau feared, as did Levinas to a lesser extent, was that someone too far removed from his inclinations would be lost in an "indifferent region," vitiated by indecision and racked with guilt. Rousseau found possible (if often practically impossible) resolutions in literature, pedagogy and political life - all things which came after the split from nature. Levinas' solution was the antecedent moment we saw above - the timeless call of God to which the subject need only respond, "here I am," and, in so doing, keep herself connected to others while also pulling herself up towards "The glory of a long desire!" (GP 144) It is something before even this antecedent moment which we will eventually come to in Derrida's critique.

That Levinas' philosophy finds some of its origins in positing the monotheistic God and transcendental philosophy against paganism is an accepted fact in some previous Levinas scholarship. The most in depth account thus far that I am aware of is in Samuel Moyn's Origins of the Other. Through meticulous archival research, Moyn shows how Levinas' writings of the early 1930s - both philosophical and popular - developed "a conception of Judaism that furnished a radically re-transcendentalizing response to the pagan philosophy of immanence that Levinas thought Heidegger was proffering in theory and Hitler was mobilizing in practice."20 But Moyn's story ends more or less in the 1930s - he does not follow these links into Levinas' later philosophy. ${ }^{21}$

Robert Bernasconi's searching essay, "Who is My Neighbor? Who is the Other? Questioning the Generosity of Western Thought," looks more generally at the various questionable moments in Levinas' oeuvre relating to other cultures. Bernasconi questions the surprising adherence Levinas has to 
the idea of Europe (particularly Husserl's formulation of it) and the ways in which Levinas' racist moments seem so out of touch with his belief in the other and his conception of Judaism as openness to the other. Bernasconi is ultimately able to separate Levinas' Eurocentrism from his philosophical texts (although he does go to great length to show their general relation) by invoking the idea of "a schema," that is, the priority of the West, "which is Levinas's but which is perhaps not properly Levinasian."22 In neither of these works, then, nor anywhere else that I have found, are we given the full picture of the adherence of Levinas' philosophy to his critique of paganism. That is what I intend to sketch here.

We can begin with Levinas' now famous essay, "Reflections on the Philosophy of Hitlerism." The reflections appeared in the Catholic journal Esprit, a venue which, as Howard Caygill has noted, was in the midst of creating a "'popular front' of the monotheistic religions against a revised paganism."23 In the essay on Hiterlism, he laid the groundwork for a surprising amount of his philosophy to come. Indeed, when Critical Inquiry reprinted the essay in 1990, Levinas included a prefatory note which briefly paraphrased the essential themes of the article in the language he had developed in the intervening fifty-six years: the critique of ontology, the subject, and freedom, and their opposition to responsibility, election, height, the face and so forth. ${ }^{24}$ The essay on Hitlerism itself, however, begins with the claim that Hitler's philosophy is based on "primitive powers" and the "awakening of elementary feelings."25

For Levinas these elementary feelings are at the root of paganism, Hiterlism and Heideggarianism, as Moyn and others have noted, since all three are marked by an inability to escape the world, and instead they remain "riveted" to it. ${ }^{26}$ It is in an essay on Maimonides the following year where Levinas more fully spells out this critique with regard to paganism. He maintains that the Jews are not the first to know of one unique God, but only the first to hear the call. This will be crucial for Levinas' later philosophy since for him the ethical encounter with the trace of a unique God in the other human being is "pre-original," that is, it is "antecedent to being." 27 Judaism's task is thus not to teach the revelation, but to continually answer the call of the other just as Abraham answers the call of God: "Here I am." As we saw above, answering this call is for Levinas the moment of selfquestioning, the moment of pulling oneself out of an immersion in being and the world in order to move toward this higher truth. Thus Levinas defines paganism as a "radical powerlessness to get out of the world." 28 While the pagan thus finds himself comforted by the world, the Jew is "stamped by suspicion," by a "silent worry," by a knowledge that one must transgress the world. Judaism, then, "is nothing...but anti-paganism."29

Levinas' arguments against "paganism" are deeply personal, and they cut across both his philosophy and religion. In a footnote to a critique of psychoanalysis from some years later, Levinas wrote, "the crisis of 
monotheism...harbors the ultimate secret of anti-semitism." 30 As we saw in the Hiterlism essay, this is the case for Levinas because only monotheism, rooted in a way of thinking and neither a race nor place, can end racism. (That Levinas himself will sneak back in a geography of thought is much of my concern here.) If monotheism cannot be returned to its rightful place alongside Greek philosophy, Levinas fears that racism will not end either. His attacks against paganism, against cultures without the novelty of the call of God, are thus at the center of his thought.

It should thus come as no surprise that these critiques of Hitlerism, Heidegger, and paganism go hand-in-hand with the development of Levinas' own philosophy, particularly his valorization of "European civilization." In On Escape, Levinas' first original philosophical essay, he develops this point explicitly. He says that the value of European civilization lies in idealism, because idealism does not rivet the spirit to the body, but rather makes room for transcendence. Although Levinas, even in the Hitlerism essay, is a critic of idealism, he appreciates this spirit of Europe, which makes possible the escape from the world.

This, more or less, is where Moyn's story of Levinas' anti-paganism ends. But perhaps the most philosophical deployment of these concerns came in 1957, the same year that Levinas published his seminal essay on Descartes' idea of infinity. In "Lévy-Bruhl and Contemporary Philosophy," Levinas shows the proximity between the thought of the anthropologist Lucien Lévy-Bruhl and several major thinkers in contemporary philosophy including Bergson, Husserl, Heidegger, and others. Levinas suggests that "to a large extent" Lévy-Bruhl's "fundamental notions" have "marked the formation of our contemporaries' fundamental concepts."31 This does not necessarily mean that Lévy-Bruhl has directly influenced all of them, or that he explains the entirety of contemporary thought. Rather, Levinas suggests that the "specific shaping" of the concepts of contemporary philosophy can be understood through the work of the great anthropologist.

It seems at first that Levinas' assessment of Lévy-Bruhl and contemporary philosophy is very positive. He argues that Lévy-Bruhl's research into "primitive mentality" has managed to dislodge the well-seated philosophical notions of category, representation, and experience. By showing that there is such a thing as a "mentality" at all, Lévy-Bruhl is able to show "that representation is not the original gesture of the human soul, but a choice, that the supposedly sovereign mens rests on a mentality" (LBCP 49). The Kantian categories of space and time, and the ensuing ability to represent reality, cannot be the basis of all possible experience, since LévyBruhl shows another possible experience - that of the primitive, the pagan, which does not rely on space or time at all.

As we perhaps have gleaned from the overview of "God and Philosophy," Levinas at some level found himself aided by this aspect of 
Lévy-Bruhl's work. He, too, was a critic of the notion of representation (to which he opposed witnessing and testimony) and of the categories of possible experience (to which he opposed the ethical experience of the other). Yet he is not content with either Lévy-Bruhl or with contemporary philosophy, and precisely because of the questions of paganism which were broached above. Levinas' argument is as follows:

Mentality...emerges from an ambivalent possibility of turning toward conceptual relations or of remaining in relationships of participation. Prior to representation it is strikingly engaged in being; it orients itself in being...And thus a perspective is opened on this new type of events which are played out below the level of representation, but nonetheless remain in relation with being. (LBCP 50)

Levinas argues here that under the conditions of Lévy-Bruhl's work we can think about thought in two ways, ultimately neither of which he finds satisfactory: it can be considered abstract and conceptual, or it can be thought of according to the "law of participation," which Lévy-Bruhl opposes to Aristotle's law of non-contradiction. Under this former law, one ignores non-contradiction and allows an object to exist simultaneously in multiple realms of being. For Lévy-Bruhl, it shows how the splitting of subject and object does not exist for the "primitive mind." But this is precisely why for Levinas the two mentalities represent a false dichotomy: they both continue to privilege being. In the former, being is preserved in Heidegger's sense as the mode of living of the being that reflects on its own being. In the latter, it is so because there simply is no separation from the world at all. Neither can activate the rupture of subjectivity that is necessary for transcendence and ethics.

Though it might appear that there is nothing wrong with either of these per se, the philosophy of Levinas we have outlined shows precisely what his concern will be: we are either too immersed in being and cannot hear the other, cannot transcend our self-enclosed world of need and consumption, or we are trapped in the intellectualism of theoretical thought which attempts to ensnare the world. Thus Levinas' ultimate conclusion is far more negative than would appear at the beginning of his essay. Lévy-Bruhl's works have ultimately done no more than "nourished a nostalgia for outdated and retrograde forms... which conveys not a broadening of reason, but a reversion to primitive mentality pure and simple." Levinas grants that there is cause to look beyond Europe, given "the insufficiency of technical reason and the catastrophes it has unleashed," but he believes that ultimately the solution cannot be found outside monotheism. Thus he concludes the essay, "But is monotheistic civilization incapable of responding to this crisis by an orientation liberated from the horrors of myths, the confusion of thought they produce, and the acts of cruelty they perpetuate in social customs?" (LBCP 51) The need for monotheistic civilization to develop a 
better response to the catastrophe of contemporary Europe than can paganism is a central task of Levinas' later works.

Totality and Infinity represents his first major attempt to answer the question and to develop an original philosophy suited to this climate of thinking. Its major idea derives from an essay on Descartes' notion of infinity published the same year as the Lévy-Bruhl piece. Thus although the latter makes only a brief appearance in the final work, the analysis of Lévy-Bruhl sets up the entire discussion of "Philosophy and the Idea of Infinity." Indeed, Levinas poses again there the question we have just seen: how do you pull out of enrootedness in being without escaping to totality? Levinas indicts Western philosophy for its failures here: "Against the turbid and disturbing participation opinion opposes, philosophy willed souls that are separate and in a sense impenetrable." This was for Levinas the right question with the wrong answer. He continues, "Thus Western thought very often seemed to exclude the transcendent." This exclusion forms in the next section of the essay a strong attack on Heidegger based in large part on what Levinas calls his desire for "pagan existing." Levinas further ups the ante on this mode of existing: "Indeed this earth-maternity determines the whole Western civilization of property, exploitation, political tyranny and war."32

From the condensed statement of his later philosophy we saw in "God and Philosophy" we can continue to see how both God and philosophy are continually described as the elements which - against this "disturbing participation" - enable the possibility of ethical subjectivity which paganism and Heideggarianism are said to deny. At the same time, the infinite desire of the other, and the other's place in my own subjectivity, safeguards against the walled-off-souls of totality. This other subjectivity begins in the height of God which pulls the subject out of the world. The call to which the subject responds is universally available. This is why for Levinas, as Bernasconi puts it, being Jewish is "not a particularity, but a modality."33 This universality, however, is inscribed in a specific response: all those monotheistic faiths which respond to "the word that one cannot help but hear, and cannot help but answer."34 Anyone can say "Here I am," indeed, according to Levinas, everyone eventually must, but that does not mean everyone already has. And yet, this does not mean for Levinas, as we see as we turn to "Peace and Proximity," that monotheism is the entire solution to the problem of paganism. Again as is clear from "God and Philosophy," the thought of turning out of the world and toward God needs to be supplemented by an intersubjective ethics, and, eventually, politics. This latter move, this ability to incarnate the Divine ethics into the realm of everyday human affairs, is the power of the combined Greek and Jewish heritage of Europe.

"Peace and Proximity" is another highly condensed statement of Levinas' philosophy, and we need not go through it in detail here. What is of concern in the brief essay is the specificity by which Levinas nominates 
Europe as the torchbearer of ethical humanity - a nomination which, again, is not merely incidental to his philosophy. Levinas opens the essay with a description of the supposed possibility of peace inaugurated by Western (Greek) thought. This is a peace of repose and sameness, a peace which has been shown to be a lie, Levinas states, by the horrors of the twentieth century. He notes that we are now seeing "the contestation of the centrality of Europe from Europe itself." Appeals are being made to a "logic other than the logic of Aristotle." Recall that Lévy-Bruhl's "law of participation" is just such a logic and it becomes clear that the issues from the 1957 essay are still very much on his mind. Levinas does not immediately refute these other logics here, but he reduces them to a general opening in the idea of Europe: Europe is not just Hellenic. Levinas believes, however, that the "vocation of Europe" does not lie in decentering itself, but rather, in opening itself up to the possibility of peace inaugurated by the Abrahamic faiths. After describing the specifics of this ethical peace, Levinas returns to Western thought: "The relation with the other and the unique that is peace comes to demand a reason that thematizes, synchronizes and synthesizes, that thinks a world and reflects on being, concepts necessary for the peace of humanity." The message here could not be clearer (at least by Levinas' standards): there can be no peace without the ethics of Jerusalem and the specific kinds of reason formulated in Greece. They are "necessary."35

And yet, even to a commentator as sensitive about such issues as Judith Butler, this insistence by Levinas does not appear worthy of much comment: "And though we might be tempted to understand this as a nefarious Eurocentrism, it is probably also important to see that there is no recognizable Europe that can be derived from this view."36 For Butler, then, a possibility of "nefarious Eurocentrism" is erased because of the indeterminacy introduced into its geographic specificity by Levinas' Hebraism, and, moreover, because Europe here represents an idea and not a continent. Be that as it may, it is clear from Levinas' essay that this idea is set against other forms of logic and reasoning, and that what should concern us here is less the nefariousness of the Eurocentrism than the way in which his insistence on Europe blocks access to other modes of thinking. In other words, even if Europe names only an idea, it still names an idea which demands the specific modes of thought (supposedly) developed in Athens and Jerusalem.

The way in which this idea of Europe remains inescapably European can perhaps be brought out further if we compare it to a recent work of philosophy, namely, Rodolphe Gasché's Europe, or the Infinite Task: A Study of a Philosophical Concept. Gasché opens the work with the story of Europa, a beautiful Asian woman violently stolen away from Zeus, who never in fact set foot in modern-day Europe. Gasché approvingly cites a definition of Europe via the myth as "'the movement of tearing away and carrying off from the paternal lands, from Asia as land..." He comments: 
What the name Europe refers to is thus not primarily the proper name of a land but a name for a movement of separation and tearing (oneself) away in which everything proper has already been left behind. It is thus an extension prior to all confinement within oneself, thus constituting an exposure to the foreign, the strange, the indeterminate. 37

Gasché attempts to put a non-discriminatory reading on this remark by speaking of Asia as land, as if the simile would anesthetize the fact that Asia is denied and Europe valorized in the reading. Moreover, the insistence on separation, as we have seen, is an insistence on denying the "pagan" attachment to the land. The thought may not be specific to Europe as geographical landmass, but it remains specific to a way of thinking that cannot be claimed as universal.

This is apparent in the book's conclusion as well, where Gasché writes that Europe names the "first addressee of this thought of uprooting oneself in order to become open to the other, a demand that goes as far as to include Europe's own de-Europeanization."38 Like Levinas, then, Gasché insists on the ethical fact of the idea of anti-paganism, on the idea of moving away from the earth and toward the openness to the other. It is also like Levinas' Europe in the sense that it is as far from the historical realty (now of antiimmigrant sentiment) as it can possibly be. ${ }^{39}$ The insistence that Europe, now as an idea and not a geographical landmass, retains the center of thought by announcing its own openness is not a progressive idea. It does nothing to create the actual openness towards the other not simply as a homogenous unit of citizenship, but rather as a thinking being whose modes of perception might change my own, including my insistence that ethics is found in "this thought of uprooting oneself in order to become open to the other." 40

\section{Gods and Philosophies Otherwise than Monotheism}

The question, then, is how is this other kind of openness achieved? Perhaps one could try to argue that the Eurocentrism really is not necessary, and that Levinas' problem is not his philosophy per se, but only the materials he used to create it. In order to do this, one need only look at the history of modern anthropology, which has sounded like one long criticism of Lévy-Bruhl. One could here argue, with modern anthropologists like Michael Taussig or Peter Geschierre, that the various forms of "paganism" do not represent a naïve immersion in the earth, but rather are themselves forms of complex reasoning and logic.41 Or with philosophical anthropologists like Eduardo Viveiros de Castro and Philippe Descola, that there are multiple, profound visions of ontology articulated the world over. 42 But, while engaging these positions in constructive dialogue with Levinas is the ultimate goal, we must note that such a critique was already available to Levinas in the work of 
Claude Lévi-Strauss, who had set out to show certain equivalences between what he called the "savage mind" and the mentality of contemporary Europe. Levinas' reply? He acknowledges Levi-Strauss' genius but then states, "But my reaction is primarily - it is I know worse than primitive - can one compare the scientific intellect of Einstein with the savage mind?"43

If Levinas is so intransigent toward positions which run contrary to his ideas, then perhaps one can just augment his position with other notions? This is, in fact, the position Butler wants to advance in Precarious Life. Citing examples of third world feminists who deny the necessity of "Western" forms of law or reason for activism, Butler concludes:

We do not need to ground ourselves in a single model of communication, a single model of reason, a single notion of the subject before we are able to act. Indeed, an international coalition of feminist activists and thinkers... will have to accept the array of sometimes incommensurable epistemological and political beliefs and modes and means of agency that bring us into activism. ${ }^{4}$

This is, indeed, the position we are trying to arrive at. It does not, however, get to the philosophical root of the problem: for Levinas one can only respond ethically by hearing the call of the other. The validity of other positions is still bound to be subsumed under his ethical rubric, whether they know it or not. Levinas himself puts it thus: the concept of Israel "already includes this abolition [of the difference between Jew, Greek and barbarian] but remains, for a Jew, a condition that is at any moment still indispensable to such an abolition, which in turn at any moment is still about to commence." 45

If Levinas then still refuses such augmentation from without, perhaps then one can augment his work from within? This was the tactic taken originally by Bernasconi, and more recently by Howard Caygill and Simon Critchley in addressing some of Levinas' political writings. Bernasconi's wandering and challenging essay returns again and again to Levinas' failure to live up to his own ethical standards. Bernasconi's solution to this problem is to inject Levinas' idea of "alterity content" into his discussion of an abstract Other. Thus he concludes, "It is the Other in his or her specific cultural difference from me that presents a direct challenge to my own cultural adherences and calls me to respond without any certainty of the appropriate way in which to respond or the idiom in which to do so."46 Bernasconi, like Butler or Lévi-Strauss, presents here an incredibly strong and complex argument, which challenges how we think about other cultures, about ethics, about the possibility for real value in inter-cultural interactions. And, like Butler's solution, it is the desired end of our discussion. But yet again, I think it is only able to dislodge Levinas' arguments if we accept the distinction between Levinas' Western schema and a thought properly Levinasian, a distinction which I have tried repeatedly to show cannot hold 
considering Levinas' 50-year engagement against paganism. In other words, even if we introduce the Other as a cultural alterity content, Levinas would still insist that only a monotheistic ear could hear that content.

But perhaps Butler puts us on the track of another possible solution when she laments that too often "we miss the situation of being addressed, the demand that comes from elsewhere, sometimes a nameless elsewhere, by which our obligations are articulated and pressed upon us." 47 Indeed, perhaps there is a solution in questioning the ear itself. What of the one who hears the call and answers, "Here I am"? What of this individual whose speech initiates the strange path Levinas will take to Europe? If the solutions of anthropology or political theory or philosophical critique seem to come after Levinas' pronouncements on culture, perhaps there is something that comes before. Perhaps there is a way to, in Levinas' own language, find something "pre-original" even to the call, which is to say, the undecidable genesis of the call itself.

In 2000, at the Jewish Community Center in Paris, Jacques Derrida gave a typically wandering talk on a very short parable by Franz Kafka. Kafka's work had only the title "Abraham," and Derrida amended the title to form his own: "Abraham, the Other." The occasion for the talk is a seemingly simple question put to Derrida: what does it mean for you to be a Jew? As Derrida weaves a talk through his childhood, through early readings of Sartre, through the horrors of memory, it is almost always Levinas who seems just around the corner.

In Kafka's brief story, as Derrida relates it, the narrator states, "'I could think of another Abraham for myself."'48 This other Abraham is not sure that he is in fact the elected one. He does not want to be like a pretentious student, who imagines that he is the receiver of praise meant for another. This other Abraham creates the possibility of not just one Abraham who was called, or of multiple Abrahams who are called, but even, Derrida will show, of no Abraham ever having been called. It is from this small possibility that Derrida's entire reading begins. It is from this possibility that Derrida will respond, if indirectly, to Levinas' Europe.

Thus, after some thirty pages of digressions, he returns to the Kafka parable which initiated the talk: "And what sense can there be in saying, in affirming, in signing, and in maintaining a 'here I am,' me a Jew, beyond sense and meaning [vouloir-dire]? In saying 'here I am,' and insisting, given that I know that perhaps I have not been called, and that perhaps I will never know it is not me who has been called" (J 30-31). As Derrida continues, his words become harsher. It is not just a self-effacing act of not wanting to over-invest in one's own worthiness. Rather, the hubris to assume that one's self is the one who is called is a transformation and corruption of the "terrible and indecisive experience of responsibility," a corruption which Derrida aligns with the worst events of the twentieth century (J 31.) Derrida 
is beginning to turn the tables on Levinas - initiating the possibility that belief in election, in the demand of the "Here I am," is as responsible for Nazism as the Heideggerian paganism Levinas set himself against.

Still without naming him, still without forcing him to be accountable to a nomination, Derrida will turn Levinas' own language against him:

Anyone responding to the call must continue to doubt, to ask himself whether he has heard right, whether there is no original misunderstanding... whether he is not in the process of substituting himself violently for another, whether the law of substitution, which is also the law of responsibility, does not call for an infinite increase of vigilance and concern. It is possible that I have not been called, me, and it is not even excluded that no one, no One, nobody, ever, called any One, any unique one, anybody. The possibility of an originary misunderstanding in destination is not an evil, it is the structure, perhaps the very vocation of any call worthy of the name, of all nomination, of all response and responsibility. (J 34; emphases mine)

Using the language of substitution, which Levinas made the centerpiece of Otherwise than Being, Derrida asks if there is not something prior to the act of substitution. For Levinas, substitution was the very first gesture of the human. The possibility that I could substitute myself for another was the possibility for all compassion and generosity in the world. And it was a possibility that was there before anything else: "The ego is not a being which is capable of expiating for others; it is this original expiation which is involuntary because prior to the initiative of the will." 49 Derrida's thoughts are aimed precisely at the structure of this prior, for it is certainly possible that the original gesture of the human is to substitute oneself for another, but, Derrida insists, it is equally the case that perhaps you are not the one being called by the other for this substitution. Perhaps it was the man or woman behind you, or to your left.

Derrida is rehearsing here a critique he made of Husserl many years before: Levinas, we might say, is imposing a "metaphysics of history in which the solid structure of a Telos would permit him to reappropriate... a wild genesis." 50 Like Husserl, the telos of Levinas' metaphysics of history is precisely Europe, Europe as the receiver of the call of the other. In denying the solid structure of the call, Derrida thus also denies an ability to name a precise genesis of the call. Hence Derrida writes that it is "no one, no One" who may have called. Perhaps the voice itself did not come from God, but from another God, who was in fact calling Abraham, but Abraham responded to yet another God. Or, even more, perhaps it is no one, because the voice which calls is polyvocal. Perhaps it really is a burning bush that calls Moses, perhaps it is the unique god of that bush, or perhaps it is God, or perhaps it is just nature and there are no gods at all. The point is simply 
that if we cannot posit a solid structure of addresser and addressee, then it is equally impossible to posit an origin or destination for the call.51

Thus, Derrida suggests, the undecidability prior to the call places on us an ethical burden other than the response, "Here I am." Rather, we must constantly be on guard to ensure that we are not responding violently in the place of another, claiming our responsibility when it is not our responsibility to claim. The claim to the uniqueness of monotheistic ethics and culture thus begins to unravel. This, Derrida states, is his Judaism, the "most intimately Jewish [thought]" (J 34). But rather than re-inscribing this other Judaism as the new unique, Derrida insists, "For you have to understand me well: when I say 'the most Jewish,' I also mean 'more than Jewish.' Others would perhaps say 'otherwise Jewish,' even 'other than Jewish'" (J 35).

This paradox of being at once the most something and more than or other than something is the final position I would like to sketch viz. a viz. Levinas' monotheistic Europe: the possibility of an otherwise than Europe, the possibility that it was not Europe that was called, but some other Europe, following some other Abraham. Otherwise than Europe is not some other to Europe, is not a call to abandon Europe or give up on its potential. Just as Levinas states that rationality maintains a place within the life-world of peace, or Derrida Jewishness within what is other than Jewish, so Europe will continue to name both a set of possibilities and a concrete historical reality.

To open up to an otherwise than Europe then, is to open up to other calls, to the undecideablity of the call. It is to say against Levinas that indeed gods or plants or animals can call the human (and each other) as much as God. ${ }^{52}$ It is also to say against Levinas that the concrete other, the alterity content of the other, as Bernasconi would say, is capable of eliciting an ethical response. ${ }^{53}$ But it is to do so by a new method, a method which works with Levinas: rather than inscribing some after, some new alterity-content, some new anthropological research, some new forms of activism, it inscribes something before, something pre-original to the call, something which comes from the genesis of the call itself: namely, that a call has no necessity to have come from some One, nor to have arrived to some one, to a destination. If Levinas' powerful description of ethical subjectivity is to be meaningful outside Europe (both as space and as idea), this Derridean opening at the origin may just make it possible.

\section{Not to be European Still}

The challenge set for this essay was to find a non-Eurocentric position from which to think the concept of ethical subjectivity in the work of Emmanuel Levinas. I hope to have shown that the position from which Levinas himself articulates it, that is, the position of Europe, at the crossroads of Athens and 
Jerusalem, of reason and response, of transcendence and height, is, from the start, inextricable from his Eurocentric critique of so-called primitive life. But this inextricability has meant only that - that the philosophy on its selfstated origins is not capable of thinking ethically in a global world open to all. It has not meant that Levinas' philosophy is therefore itself nothing other than Eurocentrism. Rather, its continued use as $a$ means of thinking ethical subjectivity has forced us to seek a non-Eurocentric origin, something more original to Levinas than Europe. In Jacques Derrida's unraveling of the call to which Abraham responds, I have suggested that such a moment can be found.

In so doing, however, I have left myself open to an obvious reply. If undedicidability at the origin is the necessary precursor for ethical thought, have we not just set up a new system of exclusions? How do we allow for thinking which does not itself accept these terms? The same reply is of course what gets asked of Butler - must we allow unreasonable propositions? - or of Bernasconi - what about an alterity content of hatred? et cetera. Indeed, it is what is asked of any philosophy whose ethics is situation-based.

The solution I would offer in reply turns the tables again - it is Levinas' reply to Derrida. In "Violence and Metaphysics," Derrida wrote, "It was a Greek who said, 'If one has to philosophize, one has to philosophize; if one does not have to philosophize, one still has to philosophize (to say it and think it). One always has to philosophize." 54 Here there is no escape from the Greek logos, even though it is Derrida himself who provided us an escape from the necessity of the Abrahamic call. It is thus left up to Levinas, in "God and Philosophy," to unhinge the logos:

Philosophy does not become suspect at just any moment in the spiritual history of the West. To recognize with philosophy - or to recognize philosophically - that the real is rational and that the rational is alone real, and not to be able to smother or cover over the cry of those who, the morrow after this recognition, mean to transform the world, is already to move in a domain of meaning which the inclusion cannot comprehend and among reasons that "reason" does not know, and which have not yet begun in philosophy...Not to philosophize would not be "to philosophize still," nor to succumb to opinions. There is meaning testified to in interjections and outcries, before being disclosed in propositions... (GP 148)

Levinas uses here another kind of logic in order to remove the necessity of Greek philosophy as the sole thing which can think the world, just as Derrida removed the necessity of monotheism. What we witness in the coupling of Derrida and Levinas, then, is not the coming together of Greek 
and Jew, but rather, quite the opposite: the undoing of the necessity of each, either together or on their own.

To the response, then, that this content-less ethics threatens to become itself a dominating logic, I can only point to this gesture as a rejoinder. What it signifies is that the means of ethical comportment have neither determinate co-ordinates in conceptual geographies, nor absolute guarantees in specific modes of thought. Ethics is an ongoing negotiation of activities and subjectivities, none of which has the right to substitute itself for others as the chosen one. One can make an ethical proposition as if it had an origin, but this will be rhetorical since the origin will never be verifiable. So that, indeed, even when one appeals to rootlessness as a European condition of ethics - as Gasché does, as Levinas does, as Derrida hedged to do at times - one can reply with Derrida against the Abrahamic strain of that Europe, and with Levinas against the Greek strain, that not to be European would not be "to be European still." This thought is neither unique to "Europe," nor is it necessarily our savior. Other ethics exist, and new ones will continue to emerge. The ethics of removal from the earth as openness to the other is an ethics, it can be a good ethics, but it is not the only good ethics, and, furthermore, as an ethics, it cannot itself have a location, nor a destination.

${ }^{1}$ After writing this paragraph I noted a similarity to the opening of Claire Katz's introduction to Emmanuel Levinas: Critical Assessments of Leading Philosophers, Volume 4 (New York: Routledge, 2005), 1. Although the overlap is unintentional, it does suggest the importance of these questions to Levinas scholarship today.

${ }^{2}$ Robert Bernasconi, "Who is My Neighbor? Who is the Other?: Questioning the generosity of 'Western Thought"' in Emmanuel Levinas: Critical Assessments, 5-30; Judith Butler, Precarious Life: The Powers of Mourning and Violence (New York: Verso, 2006); Simon Critchley, "Five Problems in Levinas' View of Politics and the Sketch of a Solution to Them" in Radicalizing Levinas, eds. Peter Atterton and Matthew Calarco (Albany: SUNY Press, 2010), 41-53; J ohn Drabinski, Levinas and the Postcolonial: Race, Nation, Other (Edinburgh: Edinburgh University Press, 2011); Nelson Maldonado-Torres, Against War: Views from the Underside of Modernity (Durham: Duke University Press, 2008).

${ }^{3}$ Quoted in Robert Bernasconi, "Who is My Neighbor? Who is the Other?," 16.

${ }^{4}$ Emmanuel Levinas, On Escape, trans. Bettina Bergo (Palo Alto: Stanford University Press, 2003), 72.

${ }^{5}$ I will, in spite of some reservations, use these terms somewhat interchangeably in what follows. This is not to remove specific histories, nor to deny the problems of the language, so much as to work through Levinas' own terms as well as to mark the failure of naming that many still experience in the face of global collectivities. 
${ }^{6}$ For a nuanced take on how the idea of "Europe" limits Levinas' ethical claims, see Drabinski, Levinas and the Postcolonial. Drabinski analyzes how a spatial idea of Europe constrains but does not overwhelm Levinas' thought, and profitably brings his work into dialogue with postcolonial philosophy, arguing that the two illuminate each other. I have no claim against this, but I do think further work clarifying how Levinas' philosophy was constituted not only by Europe as empire, but also by Europe as an idea set specifically against the "unthinking primitive," can more firmly stake out the conditions of such a dialogue. That is the hope of this essay.

${ }^{7}$ Drabinski, Levinas and the Postcolonial, vi.

${ }^{8}$ This essay has been chosen for certain thematic reasons which will become obvious, but also because of its commendation as the work which "more than any other single essay serves as a summary of Levinas' mature thought." Adriaan T. Peperzak, Simon Critchley and Robert Bernasconi, Emmanuel Levinas: Basic Philosophical Writings (Bloomington, Ind.: Indiana University Press 1996), 129.

${ }^{9}$ See, for example, Samuel Moyn Origins of the Other: Emmanuel Levinas Between Revelation and Ethics (Ithaca: Cornell University Press, 2005), 188-194; Howard Caygill, Levinas and the Political (London: Routledge, 2002), 32-3; Simon Critchley, "Five Problems in Levinas' View of Politics", 42-3.

${ }^{10}$ This essay was first presented at a venue that has taken this goal as one of its primary tasks: the California Roundtable on Philosophy and Race. My thanks to the organizers, Mickaella Perina and Falguni A. Sheth, as well as numerous good conversations with participants. I should also thank Simon Critchley, who generously opened to auditors his 2008 course on Levinas at the New School, where my thoughts on this topic first began to take shape.

${ }^{11}$ Simon Critchley, "Introduction," in Cambridge Companion to Levinas (Cambridge: Cambridge University Press, 2000), 6

12 Emmanuel Levinas, Totality and Infinity: An Essay on Exteriority, trans. Alphonso Lingis (Pittsburgh: Duquesne University Press, 1969), 154.

13 "The visage of being that shows itself in war is fixed in the concept of totality, which dominates Western philosophy" Totality and Infinity, 21.

${ }^{14}$ Emmanuel Levinas, "God and Philosophy" in Emmanuel Levinas: Basic Philosophical Writings, 130; hereafter cited as "GP."

${ }^{15}$ See Robert Bernasconi, "What is the Question to Which Substitution is the Answer?" in Cambridge Companion to Levinas, 235-236.

${ }^{16}$ Levinas goes on to various reflections on language in the essay, which do not concern us here.

${ }^{17}$ Horkheimer and Adorno also famously took up the challenge of barbarism and civilization in their critique of fascism. See Dialectic of Enlightenment, trans. Edmund J ephcott (Palo Alto: Stanford University Press, 2002) esp. chapter 1.

${ }^{18}$ Arthur Lovej oy's is a classic statement against the belief in Rousseau's primitivism: "The Supposed Primitivism of Rousseau's Discourse on Inequality" in Essays in the History of Ideas (Baltimore: J ohns Hopkins University Press, 1948), pp 14-37. See also Terry J ay Ellingson, The Myth of the Noble Savage (Berkeley: California University Press, 2001), 1-4.

19 J ean-J acques Rousseau, On the Social Contract in Basic Political Writings trans. Donald Cress (Indianapolis: Hackett, 1987), 150-51. 
${ }^{20}$ Moyn, Origins of the Other, 192.

${ }^{21}$ Moyn makes one more mention in passing, but does not flesh out the importance of his citation (Origins of the Other, 206-207).

${ }^{22}$ Bernasconi, "Who is my Neighbor? Who is the Other?," 27.

${ }^{23}$ Caygill, Levinas and the Political, 32.

${ }^{24}$ Though, as Peperzak notes, Levinas at some point in his career regretted having given Hitlerism the dignity of the title, "philosophy". Peperzak, To the Other: An Introduction to the Philosophy of Emmanuel Levinas (West Lafayette: Purdue University Press, 1993), 4.

${ }^{25}$ Levinas, "Reflections on the Philosophy of Hitlerism," trans. Seán Hand, Critical Inquiry 17 (1990), 64. Levinas will later re-claim the notion of awakening in "Philosophy and Awakening, " collected in Entre-nous: Thinking-of-the-Other trans. Michael Smith and Barbara Hashav (New York: Columbia University Press, 1998), 77-90.

${ }^{26}$ As Moyn notes, this word, rivé, which Levinas uses to describe the Heideggerian notion of "throwness," is not in common usage in French. So that he uses it in his 1932 essay on Heidegger's ontology and again in 1934 when describing the philosophy of Hitlerism shows a strong connection between the two philosophies in his mind. (Moyn, Origins of the Other, 102). Further, as we saw from Howard Caygill above, the work against paganism was part of Esprit's general program. (Caygill, Levinas and the Political, 32).

${ }^{27}$ Emmanuel Levinas, Otherwise than Being, or Beyond Essence, trans. Alphonso Lingis (Pittsburgh: Duquesne University Press, 1981), 6.

${ }^{28}$ Cited by J acque Rolland in his annotations to On Escape, trans. Bettina Bergo (Palo Alto: Stanford University Press, 2003), 91.

${ }^{29} \mathrm{Ibid}$. Moyn cites similar passages and gives a historical reading of Levinas' anti-paganism in The Origins of the Other, 186-192.

${ }^{30}$ Quoted in Bettina Bergo, Levinas Between Ethics and Politics: For the Beauty that Adorns the Earth (Pittsburgh: Duquesne University Press, 2003), 205n133.

${ }^{31}$ Levinas, "Lévy-Bruhl and Contemporary Philosophy," in Entre-nous, 41. Hereafter cited as "LBCP."

32 Levinas, "Philosophy and the Idea of Infinity" in Collected Philosophical Papers, trans. Alphonso Lingis (Pittsburgh: Duquesne University Press, 1987), 48 (emphasis mine), 52, 53. This again shows the relation of immersion in being and totality as the dual but opposite conditions of war.

33 "Who is my neighbor? Who is the other?," 19.

${ }^{34}$ Levinas, Difficult Freedom: Essays on J udaism (Baltimore: J ohns Hopkins University Press, 1997), 178.

${ }^{35}$ Levinas, "Peace and Proximity, " in Basic Philosophical Writings, 163, 164, 168; emphases mine.

${ }^{36}$ Butler Precarious Life, 136

${ }^{37}$ Rodolphe Gasché', Europe, or the Infinite Task: A Study of a Philosophical Concept (Palo Alto: Stanford University Press, 2009) 11.

${ }^{38} \mathrm{lbid}, 379$. 
${ }^{39}$ It is also remarkable that Gasché does not cite Levinas in this work, since Levinas had himself said, "It is Europe which, alongside its atrocities, invented the idea of 'deeuropeanization;' that is a victory for European generosity." (Quoted in Bernasconi, "Who is my neighbor? Who is the other?" 16

${ }^{40}$ Walter Mignolo aptly calls this kind of move a "Eurocentric critique of Eurocentrism," in Local Histories/ Global Designs (Princeton: Princeton University Press, 2000), 314.

${ }^{41}$ See The Devil and Commodity Fetishism in South America (Chapel Hill: University of North Carolina Press, 1983) and The Modernity of Witchcraft: Politics and the Occult in Postcolonial Africa (Charlottesville: University of Virginia Press, 1997), respectively.

${ }^{42}$ See The Inconstancy of the Indian soul: The Encounter of Catholics and Cannibals in 16th-century Brazil, trans. Gregory Duff Morton (Chicago: University of Chicago Press, 2011) and Beyond Nature and Culture, trans. J anet Lloyd (Chicago: Chicago University Press, 2013).

${ }^{43}$ Cited in Bernasconi, "Who is my neighbor? Who is the other?" 16.

${ }^{44}$ Butler, Precarious Life, 48.

${ }^{45}$ Levinas, Difficult Freedom, 177; emphasis mine.

${ }^{46}$ Bernasconi, "Who is my neighbor? Who is the other?" 27.

${ }^{47}$ Butler, Precarious Life, 130; emphasis mine.

${ }^{48}$ Cited in J udeities: Questions for J acques Derrida, ed. Bettina Bergo et. al. (New York: Fordham University Press 2007), 1. Original in Franz Kafka, Parables and Paradoxes (New York: Shocken, 1961). Judeities herafter cited as "J ."

${ }^{49}$ Levinas, "Substitution," in Basic Philosophical Writings, 91; emphasis mine.

50 Derrida, "The Problem of Genesis in Husserl's Phenomenology," in Writing and Difference, trans. Alan Bass (Chicago: Chicago University Press, 1978), 157.

51 Such a structure of thought might open to a rapport with what Viveiros de Castro calls "Amerindian multi-naturalism": "Where[as] [multiculturalism is] founded on the mutual implication of the unity of nature and the plurality of cultures...the Amerindian conception would suppose a spiritual unity and a corporeal diversity. Here, culture or the subject would be the form of the universal, whilst nature or the object would be the form of the particular." Thus, it is not a matter of a single God who is heard differently by different cultures, but rather of multiple natures that are universally related to, albeit differentially. Eduardo Viveiros de Castro, "Cosmological Deixis and Amerindian Perspectivism." Journal of the Royal Anthropological Institute 4.3 (1998): 470.

52 On Levinas' need to open to animals, see David Wood, "Some Questions for my Levinasian Friends," in Addressing Levinas (Evanston: Northwestern University Press, 2005), pp 152-169. On plants and nature more generally, See Graham Harman, Tool-Being: Heidegger and the Metaphysics of Objects (Peru, Illinois: Open Court Press 2002), 242-243.

${ }^{53}$ Enrique Dussel in Philosophy of Liberation (Maryknoll, NY: Orbis Books 1985) and Adi Ophir in The Order of Evils: Toward an Ontology of Morals (New York: Zone Books 2005), have also insisted on opening Levinas to the concrete and not just the abstract other.

${ }^{54}$ Derrida, "Violence and Metaphysics" in Writing and Difference, 152. 